\title{
PERBANDINGAN PENGGUNAAN METODE SAW DAN AHP UNTUK SISTEM PENDUKUNG KEPUTUSAN PENERIMAAN KARYAWAN BARU
}

\author{
Arista Qiyamullaily ${ }^{1}$, Silvia Nandasari ${ }^{2}$, Yusuf Amrozi ${ }^{3}$ \\ Sistem Informasi, Fakultas Sains dan Teknologi \\ Universitas Islam Negeri Sunan Ampel, Surabaya, Indonesia \\ e-mail : ${ }^{1}$ aristaqiyamullailiy@gmail.com, ${ }^{2}$ silviananda0818@gmail.com, ${ }^{3}$ yusuf.amrozi@uinsby.ac.id \\ Diterima: 6 Desember 2019. Disetujui : 20 Juni 2020. Dipublikasikan : 30 Juni 2020 \\ (C)2020 -TESJ Fakultas Teknik Universitas Maarif Hasyim Latif. Ini adalah artikel dengan \\ akses terbuka di bawah lisensi CC BY 4.0 (https://creativecommons.org/licenses/by/4.0/)
}

\begin{abstract}
ABSTRAK
Dengan menggunakan konsep Decision Support System (DSS) akan membantu manusia untuk pengambilan keputusan dengan mudah. Salah satu pemanfaaatan DSS yakni dalam penerimaan karyawan baru. Dengan beberapa metode yang digunakan untuk DSS. Penulis membandingkan metode SAW dan AHP yang sangat banyak digunakan dalam manajemen perusahaan di Indonesia. Metode penelitian pada artiel ini adalah uji pustaka yaitu mendiskripsikan konsep dan implementasi dari penelitian yang terdahulu yang terkait. Dengan uji pustaka perbandingan antara model AHP dan SAW akan lebih mudah dan jelas. Hasil dari uji pustaka ini yaitu data yang dimasukkan dalam jumlah besar lebih relevan menggunakan metode SAW dan apabila data yang akan diinputkan lebih sedikit maka menggunakan metode AHP akan lebih relevan untuk diimplementasikan.
\end{abstract}

Kata kunci: decision support system, simple additive weight, analytical hierarcy process

\section{PENDAHULUAN}

Decision support system adalah sistem yang berbasis komputer, hampir selalu interaktif, dan dirancang untuk membantu seorang manajer dalam membuat keputusan (Wainright \& Martin, 2002). Sedangkan menurut Sprague (Sprague \& Watson, 1993), DSS adalah suatu sistem informasi yang dapat atau bisa diharapkan untuk membantu manajemen dalam proses pengambilan keputusan.

Dengan adanya pengambilan keputusan dengan memanfaatkan sistem informasi akan meringankan tugas manajer dan menghasilkan keputusan yang begitu efisien dan efektif. Decision support system juga memilliki tujuan yang sangat relevan yakni membantu menjawab masalahmasalah semi terstruktur dalam perusahaan atau organisasi tersebut.

Sistem pendukung keputusan memiliki banyak cara yang dapat dipakai. Metode atau cara yang sangat terkenal di kalangan perusahaan adalah metode fuzzy Simple Additive Weight (SAW) dan metode AHP. Metode fuzzy SAW adalah metode yang digunakan dengan salah satu cara yakni mencari penjumlahan terbobot dari rating kinerja pada setiap alternatif pada semua atribut (Kusumadewi \& Hartati, 2006). Sedangkan metode Analytical Hierarchical Process (AHP) merupakan metode yang digunakan untuk mencari urutan atau rangking prioritas dari beberapa alternative dalam pemecahan masalah (Saaty, 1970).
Dua metode tersebut mengambil keputusan dengan cara atau model yang sama yakni mengambil keputusan berbentuk rangking. Penerapan DSS tersebut dapat dianalisis dan menjadi pertimbangan pemilihan metode yang lebih unggul dalam mengambil keputusan untuk penerimaan karyawan terbaik dalam beberapa perusahaan.

\section{METODE PENELITIAN}

Metode penelitian pada penelitian ini adalah uji pustaka yaitu mendiskripsikan konsep dan implementasi dari penelitian yang terdahulu yang terkait. Dengan uji pustaka perbandingan antara model AHP dan SAW akan lebih mudah dan jelas. Salah satu jurnal yang menjadi referensi dalam jurnal ini adalah Perbandingan AHP dan SAW untuk pemilihan pegawai terbaik.

\section{Decision Support System}

Decision support system merupakan suatu sistem informasi yang diharapkan dapat membantu manajemen dalam proses pengambilan keputusan (Sprague \& Watson, 1993). Sistem pengambilan keputusan ini sangatlah dibutuhkan oleh perusahaan-perusahaan dikarenakan manfaat yang sangat berguna. Sistem pengambil keputusan tidak diimplementasikan untuk menggantikan manajer- 


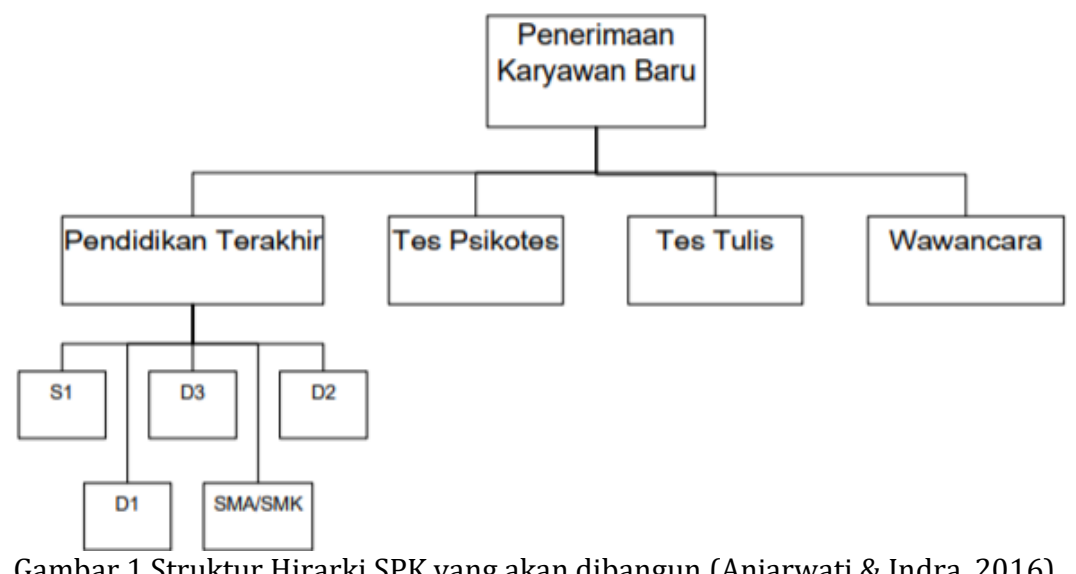

manajer melainkan menjadi sarana penunjang (tools) bagi manajer. Tujuan penggunakan sistem pengambilan keputusan yakni membantu menjawab masalah semi terstuktur, membantu manajer dalam mengambil keputusan, dan pastinya menghasilkan keputusan yang lebih efektif dan efisien.

\section{Analytical Hierarchy Process (AHP)}

Metode yang digunakan dalam mengimplementasikan sistem pendukung keputusan sangatlah banyak. Dua diantaranya adalah metode AHP dan SAW. AHP adalah sebuah metode yang dikembangkan pada tahun 1970 oleh Thomas L Saaty. AHP adalah metode yang digunakan untuk mencari urutan atau rangking prioritas dan berbagai alternative pemecahan pengambilan keputusan (Saaty, 1970).

\section{Simple Additive Weighting (SAW)}

Yang kedua adalah SAW, menurut Fishburn dan MacCrimmon adalah konsep dasar metode SAW adalah mencari penjumlahan terbobot dari rating kinerja pada setiap alternatif pada semua atribut (Munthe, 2013). SAW adalah mencari penjumlahan terbobot dari rating kinerja pada setiap alternatif pada semua atribut (Kusumadewi \& Hartati, 2006). Kedua metode ini memiliki kesamaan yaitu mengaplikasikan sistem pendukung keputusan menggunakan konsep mencari urutan atau rating dalam mencari alternative terbaik.

\section{HASIL DAN PEMBAHASAN}

Salah satu masalah yang sering menggunakan sistem pendukung keputusan pada beberapa perusahaan yakni penerimaan karyawan baru. Dalam hal ini, sistem pedukung keputusan akan lebih membantu para manajer untuk mempertimbangkan dalam penerimaan tersebut. Dengan beberapa metode yang sudah dijelaskan di atas, penulis akan membandingkan antara metode
SAW dan metode AHP dalam permasalahan penerimaan karyawan baru.

Pada penelitian terdahulu penerimaan karyawan baru menggunakan metode AHP dan SAW membuat struktur hirarki untuk sistem pendukung keputusan. Metode AHP menggunakan struktur hirarki denga 3 level yakni level pertama adalah tujuan, level kedua adalah kriteria, dan level ketiga adalah subkriteria. Berikut adalah gambaran dari struktur hirarki dengan menggunakan metode AHP. Gambar 1 diambil dari penelitian jurnal VOI STMIK Tasikmalaya vol 5 nomer 2 dengan judul Sistem Pengambil Keputusan Penerimaan Karyawan Baru Menggunakan Metode Analytical Hierarchy Process (AHP) pada PT. Tunas Bersama Yamansari Kabupaten Tegal

Proses selanjutnya setelah merangkai struktur hierarki adalah menghitung vector prioritas. Setelah perhitungan Panjang dan menemukan hasil, maka matriks yang telah diproses harus dilakukan normalisasi untuk proses kriteria. Hasil yang telah melewati normalisasi akan menentukan konsistensi logis proses akan melakukan konsistensi sesuai dengan metode AHP. Adapun langkah-langkah yang harus dilakukan adalah: (Umar, Fadlil, \& Yuminah, 2018)

1) Menghitung nilai perbandingan yang sudah ditetapkan dengan membagi nilai skala yang ada di setiap sel dibagi dengan nilai sel prioritas.

2) Hasil pehitungan dari langkal no. 1 di masingmasing sel dibagi dengan jumlah total di masingmasing kolom.

3) Mencari Eigen dengan cara menghitung ratarata per baris.

4) Mencari Lamda ( $\lambda$ ) dengan cara mengalikan masing-masing nilai eigen per baris dengan jumlah total per kolom.

5) Mencari lamda ( $\lambda$ maks) dengan cara menjumlahkan hasil lamda

Menentukan nilai indeks konsistensi (CI) menggunakan persamaan sebagai berikut:

dengan: 
$n$ : banyaknya kriteria

Menetukan rasio konsistensi ( $C R$ ) menggunakan persamaan sebagai berikut:

$$
C R=\frac{C I}{R I}
$$

dengan:

$C R$ : Rasio Konsistensi

$C I$ : Indeks Konsistensi

$R I$ : Indeks Random Konsistensi

Apabila proses yang sudah dihitung dengan hitungan Consistency Ratio mendapatkan hasil ratio kurang dari 0.1 atau $10 \%$ makan disimpukan bahwa vector prioritas kriteria konsisten. Proses dilakukan ulang untuk menghitung level tiga yakni subkriteria. Dan jika hitungan Consistency Ratio kurang dari 0.1 atau $10 \%$ subkriteria juga disimpulkan konsisten.

Terakhir menghitung nilai konversi, total dan menghitung hasil nilai seleksi akan memunculkan hasil dan keterangan apakah karyawan baru diterima atau ditolak. Berikut pada Tabel 1 adalah contoh hasil penerimaan karyawan baru dengan metode AHP.

Tabel 1. Hasil Penerimaan Karyawan Baru dengan metode AHP (Anjarwati \& Indra, 2016)

\begin{tabular}{|l|l|l|l|}
\hline Wawancara & $\begin{array}{l}\text { Nilai } \\
\text { Total }\end{array}$ & $\begin{array}{l}\text { Standar } \\
\text { Nilai }\end{array}$ & Keterangan \\
\hline 34 & 85.905 & 70 & Diterima \\
\hline 30 & 73.26 & 70 & Diterima \\
\hline 30 & 56.025 & 70 & Ditolak \\
\hline
\end{tabular}

Dan untuk metode SAW pada penelitian yang sudah pernah diselenggarakan oleh pihak terkait, metode ini menggunakan proses dasar yaitu proses normalisasi matrik keputusan $(x)$ ke suatu skala yang dapat dibandingkan dengan semua rating alternatif yang ada. Proses diawali dengan memberi nilai di setiap alternatif pada setiap kriteria yang kedua yaitu memberikan nilai bobot pada berdasarkan nilai keanggotaan. Setelah pemberian nilai bobot maka melakukan proses normalisasi pada matriks (Kusumantara, Kustyani, \& Ayu, 2019). Persamaan yang digunakan untuk normalisasi pada rating kinerja adalah:

$$
\begin{aligned}
& r_{i j}= \begin{cases}\frac{X_{i j}}{\operatorname{Max} X_{i j}} & ; \text { Jika } j \text { adalah atribut keuntungan (benefit) } \\
\frac{\operatorname{Min} X_{i j}}{X_{i j}} & ; \text { Jika } j \text { adalah atribut biaya (cost) }\end{cases} \\
& \text { Keterangan : } \\
& r_{i j} \quad=\text { Nilai rating kinerja ternomalisasi. } \\
& x_{i j} \quad=\text { Nilai atribut yang dimiliki dari setiap alternatif. } \\
& \text { Max = Nilai terbesar. } \\
& \text { Min = Nilai terkecil. } \\
& \text { Benefit = Jika nilai terbesar adalah terbaik. } \\
& \text { Cost = Jika nilai terkecil adalah terbaik. } \\
& \text { Dimana } r_{i j} \text { adalah rating kinerja ternomalisasi dari alternatif } A_{i} \text { pada atribut } \\
& C_{j} ; i=1,2, \ldots, \mathrm{n} \text {. }
\end{aligned}
$$

Dengan begitu proses akan berlanjut dengan melakukan proses perangkingan dan nilai terbesar adalah alternate terbaik untuk setiap alternatif yang ada. hasil yang telah dilakukan akan menampilkan karyawan yang diterima ataupun ditolak oleh perusahaan tersebut. Pada Tabel 2 adalah contoh hasil penerimaan karyawan baru dengan menggunakan metode SAW.

Tabel 2. Hasil Penerimaan Karyawan Baru dengan metode SAW

\begin{tabular}{ccccc}
\hline \multirow{2}{*}{ Alternatif } & \multicolumn{4}{c}{ Kriteria } \\
\cline { 2 - 5 } & Karakter & Keahlian & Kecakapan & Penampilan \\
\hline $\mathrm{A}_{1}$ & 0.4 & 0.6 & 0.4 & 0.4 \\
\hline $\mathrm{A}_{2}$ & 0.6 & 0.6 & 0.2 & 0.4 \\
\hline \multirow{2}{*}{ Alternatif } & \multicolumn{4}{c}{ Kriteria } \\
\cline { 2 - 4 } & Test & Usia & Wawancara & \multirow{2}{*}{ Hasil } \\
\hline $\mathrm{A}_{1}$ & 0.6 & 0.4 & 0.4 & 5 \\
\hline $\mathrm{A}_{2}$ & 0.4 & 0.8 & 0.4 & 4.27 \\
\hline
\end{tabular}

Untuk menentukan perbandingan dalam penggunaan dua metode tersebut beberapa penelitian juga membandingkan dengan cara manual atau tanpa sistem aplikasi AHP atau SAW yakni membandingkan dengan Microsoft Excel. Hasil dari penelitian perbandingan dengan Mcrosoft Excel sebagaimana pada Tabel3.

Tabel 3. Hasil perhitungan dengan 75 data (Tanpa AHP maupun SAW) (Sunardi \& Kriestanto, 2016)

\begin{tabular}{cllll}
\hline \hline NPP & \multicolumn{1}{c}{ Nama } & \multicolumn{1}{c}{ Pangkat } & Gol & Nilai \\
\hline 852076 & Zainudin & Penata Muda & II-D & 91,74 \\
962099 & Heribertus Sri Widada & Pengatur Tk 1 & II-D & 89,65 \\
962092 & Andi Setiyanto & Pengatur Muda & II-A & 89,46 \\
992120 & Nakif jauhari & Juru Tk 1 & I-D & 88,82 \\
892022 & Nuryuningsih & Penata Muda & III-A & 88,67 \\
992121 & Achmad Muritno & Penata Muda & III-A & 87,33 \\
982112 & Puji Raharjo & Juru Tk 1 & I-D & 86,71 \\
962073 & St. Suharmanto & Penata Muda & III-A & 86 \\
952064 & Victoria Sudarmi & Penata Muda & III-A & 85,94 \\
942046 & Bambang Budi Utomo & Penata Tk 1 & III-D & 85,82 \\
942053 & Suharto & Penata Muda & III-A & 85,79 \\
012131 & Ari Yuniarto & Pengatur Tk 1 & II-D & 85,72 \\
\hline \hline
\end{tabular}

Tabel 4. Hasil perhitungan dengan 100 data (Tanpa AHP maupun SAW) (Sunardi \& Kriestanto, 2016)

\begin{tabular}{cllll}
\hline \hline NPP & \multicolumn{1}{c}{ Nama } & \multicolumn{1}{c}{ Pangkat } & Gol & Nilai \\
\hline 852076 & Zainudin & Penata Muda & II-D & 91,74 \\
962099 & Heribertus Sri Widada & Pengatur Tk 1 & II-D & 89,65 \\
962092 & Andi Setiyanto & Pengatur Muda & II-A & 89,46 \\
992120 & Nakif jauhari & Juru Tk 1 & I-D & 88,82 \\
892022 & Nuryuningsih & Penata Muda & III-A & 88,67 \\
052163 & Suraji & Penata Muda & III-A & 88,59 \\
942150 & Tarom & Pengatur Tk 1 & II-D & 88,11 \\
932149 & Eka Wahyu & Penata Muda & III-A & 88,05 \\
992121 & Achmad Muritno & Penata Muda & III-A & 87,33 \\
032158 & Putra & Pengatur Tk 1 & II-A & 86,89 \\
982112 & Puji Raharjo & Juru Tk 1 & I-D & 86,71 \\
962073 & St. Suharmanto & Penata Muda & III-A & 86 \\
952064 & Victoria Sudarmi & Penata Muda & III-A & 85,94 \\
022155 & Karmin & Penata Muda & I-D & 85,91 \\
942046 & Bambang Budi Utomo & Penata Tk 1 & III-D & 85,82 \\
942053 & Suharto & Penata Muda & III-A & 85,79 \\
012131 & Ari Yuniarto & Pengatur Tk 1 & II-D & 85,72 \\
032152 & Rangga & Pengatur Tk 1 & II-D & 85,72 \\
992139 & Arya & Penata Muda & I-D & 85,69 \\
042159 & Rahmat & Pengatur Tk 1 & II-C & 85,67 \\
862145 & Tika & Juru Tk 1 & III-A & 85,66 \\
022161 & Sugandam & Penata Muda & III-A & 85,5 \\
022154 & Arman & Pengatur Muda & II-D & 85,07 \\
\hline \hline
\end{tabular}


Sedangkan menggunakan aplikasi dengan metode SAW dan AHP akan menghasilkan seperti pada Tabel 5.

Tabel 5. Hasil dari metode AHP dan SAW dengan 75 data (Sunardi \& Kriestanto, 2016)

\begin{tabular}{|c|c|c|c|}
\hline \multicolumn{2}{|c|}{ Metode AHP } & \multicolumn{2}{|c|}{ Metode SAW } \\
\hline NAMA & NILAI & NAMA & NILAI \\
\hline Zainudin & 92.43 & Zainudin & 93.86 \\
\hline Andi Setiyanto & 88.72 & Andi Setiyanto & 91.89 \\
\hline Nuryuningsih & 88.52 & Heribertus Sri Widada & 91.88 \\
\hline Heribertus Sri Widada & 88.12 & Nakif jauhari & 91.31 \\
\hline Bambang Budi Utomo & 87.47 & Nuryuningsih & 90.50 \\
\hline Puji Raharjo & 87.39 & Sri Wahyuni & 88.67 \\
\hline Nakif jauhari & 87.37 & St. Suharmanto & 88.49 \\
\hline $\begin{array}{l}\text { Suharto } \\
\text { Sult }\end{array}$ & 87.04 & Achmad Muritho & 88.41 \\
\hline St. Suharmanto & 86.87 & Bambang Budi Utomo & 88.27 \\
\hline Achmad Muritno & 86.66 & Suharto & 87.96 \\
\hline & 85.64 & Puji Raharjo & 87.83 \\
\hline \multirow{4}{*}{ Victoria Sudarmi } & 85.42 & Victoria Sudarmi & \\
\hline & & Ari Yuniarto & 86.91 \\
\hline & & Rully Anggoro & 85.66 \\
\hline & & Siswoyo & 85.24 \\
\hline
\end{tabular}

Setelah melihat hasil penelitian tiga alternatif pencarian karyawan baru yakni metode lama yaitu Microsoft Excel ataupun dua metode sistem pengambilan keputusan dengan metode SAW dan AHP dapat dilihat bahwa dua metode aplikasi ini mempunyai perbedaan yang sangat sedikit. Apabila dilihat dari proses pencarian algoritma maka bisa dikatakan dua metode ini adalah dua metode yang hampir sama dengan mencari kriteria dan penilaian bobot menjadi prioritas. Namun, jika dilihat dari hasil alternatif pada percobaan di atas dua metode yang lebih efisien dan sesuai dengan metode Microsoft Excel adalah metode SAW.

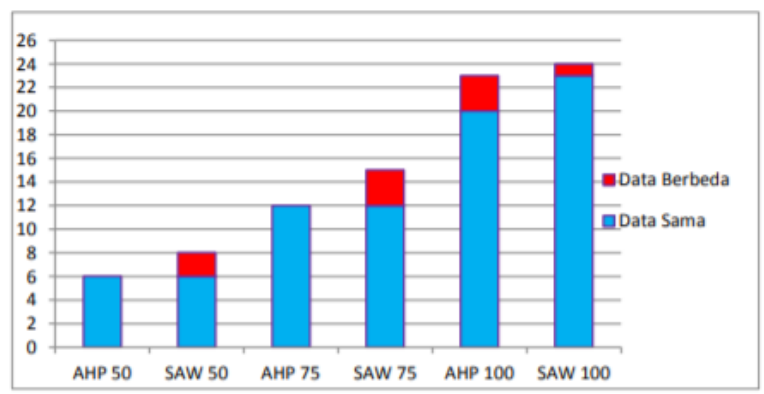

Gambar 2. Grafik Hasil Perbandingan AHP dan SAW

Dari Gambar 2, terlihat sistem AHP dan SAW mempunyai keunggulan masing-masing tergantung berapa input atau data diproses didalamnya. Dengan menggunakan data 50 dan 75 sistem dengan metode AHP yang terbaik dikarenakan keakuratan yang didapat adalah $100 \%$ namun ketika data dinaikkan menjadi 100 data metode SAW akan lebih unggul karena alternatif yang digunakan perbedaannya lebih sedikit daripada penggunaan metode AHP.

\section{PENUTUP}

Setelah melakukan uji pustaka terhadap beberapa penelitian terdahulu tentang sistem pengambilan keputusan dengan membandingkan dua metode yakni metode SAW dan AHP. Kemudian, dibandingkan dengan metode lama atau tanpa aplikasi sistem pendukung keputusan yaitu Microsoft Excel menunjukkan hasil dalam kasus penerimaan karyawan baru dapat disimpulkan bahwa metode AHP dan SAW mempunyai kesamaan dalam efektif dan relevan. Namun, dalam kasus ini mengimplementasikan dua metode tergantung berapa jumlah data yang diproses. Apabila, data yang diprose dalam jumlah besar maka lebih relevan menggunakan metode SAW dan apabila data yang akan dimasukkan lebih sedikit maka menggunakan metode AHP akan lebih relevan untuk diimplementasikan.

\section{DAFTAR PUSTAKA}

Amrozi, Y. (2017). Simulasi dalam Manajemen Pengambilan Keputusan menggunakan AHP. Seminar Nasional Teknologi Informasi Komunikasi Dan Industri, 736-746.

Anjarwati, S., \& Indra, M. S. N. (2016). Sistem Pendukung Keputusan Penerimaan Karyawan Baru Menggunakan metode Analytical Hierarchy Process pada PD Tunas Bersama Yamansari Kabupaten Tegal. Jurnal VOI (Voice Of Informatics), 5(2).

Destari, S., \& Simpony, B. K. (2018). Sistem Pendukung Keputusan Untuk Menentukan Wedding Organizer Menggunakan Metode AHP. IJCIT (Indonesian Journal on Computer and Information Technology), 3(2).

Fashoto, S. G., Amaonwu, O., \& Afolorunsho, A. (2018). Development of A Decision Support System on Employee Performance Appraisal using AHP Model. JOIV: International Journal on Informatics Visualization, 2(4), 262-267.

Kusumadewi, S., \& Hartati, S. (2006). Neuro-Fuzzy: Integrasi Sistem Fuzzy dan Jaringan Syaraf. Yogyakarta: Graha Ilmu.

Kusumantara, P. M., Kustyani, M., \& Ayu, T. (2019). Analisis Perbandingan Metode SAW Dan WP Pada Sistem Pendukung Keputusan Pemilihan Wedding Organizer Di Surabaya. Teknika: Engineering and Sains Journal, 3(1), 19-24.

Munthe, H. G. (2013). Sistem Pendukung Keputusan Penentuan Prioritas Usulan Sertifikasi Guru Dengan Metode Simple Additive Weighting. Pelita Informatika Budi Darma, 4(2).

Nurmi, A. A., \& Aklani, S. A. (2014). Membangun Decision Support System (DSS) Online Penelitian Dosen Dengan Metode Analytical Hierarchycal Process (AHP).

Saaty, T. L. (1970). Multicriteria Decision Making: The Analytic Hierarchy Process: Planning, Priority Setting Resource Allocation. 1990. RWS Publications, Pittsburgh City, PA. 
Saputra, Y. A., \& Indonesia, T. I. (2014). Implementasi Augmented Reality (AR) Pada Fosil Purbakala di Museum Geologi Bandung. Jurnal Ilmiah Komputer Dan Informatika (KOMPUTA), 1-8.

Sprague, R. H., \& Watson, H. J. (1993). Decision Support Systems: Putting Theory Into Practice. Englewood Clifts. NJ, Prentice Hall.

Sunardi, T. B., \& Kriestanto, D. (2016). Perbandingan AHP Dan Saw Untuk Pemilihan Pegawai Terbaik (Studi Kasus: Stmik Akakom Yogyakarta). Teknik Infomatika, Stmik Akakom Yogyakarta, Seminar Riset Teknologi Informasi (SRITI) Tahun 2016.
Supriyatna, A., \& Ekaputra, D. (2017). Metode Fuzzy Simple Additive Weighting (Saw) Dalam Pemilihan Ketua Osis. Jurnal PETIR, 10(1), 71-76.

Umar, R., Fadlil, A., \& Yuminah, Y. (2018). Sistem Pendukung Keputusan dengan Metode AHP untuk Penilaian Kompetensi Soft Skill Karyawan. Khazanah Informatika: Jurnal Ilmu Komputer Dan Informatika, 4(1), 27-34.

Wainright, E. M., \& Martin, E. W. (2002). Managing information technology. Prentice Hall. 
A Qiyamullaily, dkk / Teknika : Engineering and Sains Journal, Vol. 4, No.1, Juni 2020, 7-12

halaman ini sengaja dikosongkan 